\title{
ЦАГИРАГ БА ИНВОЛЮЦТЭЙ ЦАГИРАГУУД РАДИКАЛЫН ХАМААРЛЫН ТУХАЙ
}

\author{
С.Төмөрбат ${ }^{1}$, Ш.Батхиииг 2 \\ ${ }^{1}$ Математикийн тэнхим, Монгол Улсын Их Сургууль, Монгол улс \\ ${ }^{2}$ Математикийн тэнхим, Монгол Улсын Боловсрольн Их Сургууль, Монгол улс \\ Цахим шуудан: stumurbat@hotmail.com
}

Редакиид ирҮҮлсэн: 2016.02.02

Удирдтгал: Бид инволюи радикальг тодорхойлж, уламжлагдах инволюи радикалын чанаруудыг батлахын зэрэгиээ энгийн цагирагууд хуваалт авч өмнөх үр дүнгээс хүчтэй үр дүн баталсан.

ТүлхуУр үгс: Радикал онол, инволюитэй изагираг, тусгай радикал.

Энэхүу өгүүлэлд авч үзэж буй цагирагууд нь нэгжтэй байх албагүй ассоциатив цагирагууд юм.

Цагирагуудын анги $M$ ийн хувьд хэрэв

(i) $M$ гомоморфизмын хувьд битүу

(ii) $M$ нь уламжлагдах (өөрөөр хэлбэл $I \triangleleft A \in M$ гэдгээс $I \in M$ )

нөхцӨлүУдийг хангах бол универсаль анги гэж нэрлэнэ.

Заншил ёсоор $A$ цагиргийн идеалыг $I \triangleleft A$ гэж тэмдэглэдэг.

Цагирагуудын универсаль анги $M$ дахь $\gamma$ анги нь

(i) Гомоморфизмын хувьд битүу; өөрөөр хэлбэл (Хэрэв $I \triangleleft A$ ба $A \in \gamma$ бол $A / I \in \gamma)$.

(ii) Өргөтгөлийн хувьд битүү, өөрөөр хэлбэл $(I \triangleleft A$ идеалын хувьд $I \in \gamma$ ба $A / I \in \gamma$ бол $A \in \gamma)$.

(iii) Индуктив чанартай, өөрөөр хэлбэл (Хэрэв $I_{1} \subseteq \ldots \subseteq I_{\lambda} \subseteq \ldots, A=\bigcup A_{\lambda}$ ба $I_{\lambda} \in \gamma$ бол $\left.A \in \gamma\right)$.

нөхцөлүүдийг хангаж байвал Курош-Амииурын радикал гэж нэрлэдгийг сануулъя. Инволюцтэй цагирагийн радикал ангид ADS нөхцөл биелдэггүй, харин ердийн цагирагийн ангид ADS биелдэг нь энэ хоёр ангийн гол ялгаа. Цаашид бид товчоор радикал анги гэж нэрлэх болно.

Өгөгдсөн радикал $\gamma$ болон дурын цагираг $A \in M$ ийн хувьд $A$ нь хамгийн том $\gamma$-идеалыг агуулах бөгөөд түүнийг $\gamma_{M}(A)$ гэж тэмдэглэе. Түүнийг $A$ цагиргийн радикал гэнэ. 
Түлхүур үгс: Радикал онол, инволюцтэй цагираг, тусгай радикал.

Хэрэв $\gamma_{M}$ радикал анги бол

$$
S\left(\gamma_{M}\right)=\left\{A \in M \mid \gamma_{M}(A)=0\right\}
$$

Үүнийг $\gamma_{M}$ радикалын хагас энгийн анги гэнэ.

Цагиргуудын анги $M$ ийн дэд анги $M_{0} \subseteq M$ ийн хувьд хэрэв $0 \neq I \triangleleft A \in M_{0}$ идеал бүр нь $M_{0}$-д харъяалагдах тэгээс ялгаатай гомоморф дүртэй бол регуляр анги гэж нэрлэдэг. Тухайн тохиолдолд $I \triangleleft A \in M \Rightarrow I \in M$ бол уламжслагдах анги гэж нэрлэх бөгөөд тэр нь регуляр анги байна.

Бид регуляр анги $M_{0} \subseteq M$ ийг авч үзэж $U_{M}$ гэсэн дээд радикал анги тодорхойлох операторыг дараах байдлаар авч үзье.

$$
U_{M}\left(M_{0}\right)=\left\{A \in M \mid A \text { нь } M_{0} \text {-д тэгээс ялгаатай гомоморф дүргүй }\right\} .
$$

Радикал онолын суурь чанаруудыг [1], [2], [3] бүтээлүүдээс харж болно.

Ассоциатив цагирагуудын ангид нэмэлт оператор * -г тодорхойлж, хэрэв оператор * нь $A$ цагиргийн дурын $a, b \in A$ хувьд $a^{* *}=a,(a+b)^{*}=a^{*}+b^{*},(a b)^{*}=b^{*} a^{*}$ нөхцөлийг хангаж байвал $A$-г инволюитай иагираг гэж нэрлэдэг. Бүх инволюцтай цагиргийн ангийг $\mathcal{A}^{*}$ гэж тэмдэглэе. Бүх ассоциатив цагиргуудын ангийг Ass гэж тэмдэглэе. $\gamma$-нь $A s s$-д радикал байг. Хэрэв дурын $A \in \gamma$ цагираг нь инволюцтэй бол инволюцэн радикал гэж нэрлэе. $A$ цагираг инволюцтэй бөгөөд $B$-нь $A$ ийн дэд цагираг байх үед $B^{*}=\left\{b^{*} \in A \mid b \in B\right\}$ гэж тэмдэглэе. Хэрэв $B^{*}=B$ бол *-дэд иагираг гэдэг.

$B=B_{1} \unlhd B_{2} \unlhd \ldots \unlhd A$ байх $B$ дэд цагирагийг accessibly (боломжит) дэд цагираг гэнЭ.

$$
\mathcal{A}=\left\{A \in \mathcal{A}^{*} \mid A \text { ийн дурын боломжит дэд цагираг нь *-дэд цагираг }\right\}
$$

Жишээ 1.1. Дурын коммутатив чагираг $\mathcal{A}$-д харв.яалагдана.

Үүнд инволюц нь адилтгал $(i d)$ болно.

Жишээ 1.2. Дурын инволюитэй энгийн цагираг $\mathcal{A}$-д харглалагдана. Мөн хуваалтын иагираг $D$ дээр $n \times n$ эрэмбийн $M_{n}(D)$ цагираг $\mathcal{A}$-д харбляалагдана.

Баталгаа. Үнэхээр, $D$-нь $\nabla$-гэсэн инволюцтэй бол бид $\left(a_{i j}\right)^{*}=\left(a_{i j}^{\nabla}\right)$ гэж тодорхойлоход хангалттай.

Өгүулбэр 1.3. $\mathcal{A}$-нь бүх цагирагуудън ангид универсаль дэд анги байна.

Баталгаа. Инволюцтэй цагирагийн гомоморф дүр нь инволюцтэй байх нь илэрхий. Үүнд инволюцтэй цагирагийн гомоморф дүр гэдгийн дор инволюцтэй идеалаар факторлорыг ойлгоно. Иймд инволюцтэй цагирагийн гомоморф дүр инволюцтэй байна. Уламжлагдах байх нь $\mathcal{A}$-ийн тодорхойлолтоос гарна. 
Иймд $\mathcal{A}$-ангид радикал тодорхойлж болох учраас $\mathcal{A}$-дахь $\gamma$ радикалыг авч үзэж $\gamma$-аар төрөгдсөн $A s s$ дахь радикалыг $l_{A s s}(\gamma)$-гэж тэмдэглэе.

[8] -өгүүлэл дэх харгалзах үр дүнгүҮдийн баталгаатай төстэйгээр дараах үр дүнгүүдийг баталж болно.

Лемм 1.4. $\gamma=l_{\text {Ass }}(\gamma) \cap \mathcal{A}$.

Лемм 1.5. Хэрэв $\gamma$ нъ Ass -д радикал бол $\gamma \cap \mathcal{A}-н ъ \mathcal{A}-д$ радикал байна.

Теорем 1.6. $\gamma$ нь Ass -д яммар нэг радикал байг. Тэгвэл $\gamma \cap \mathcal{A}=l_{\text {Ass }}(\gamma \cap \mathcal{A}) \cap \mathcal{A}$.

Лемм 1.4, лемм 1.5, теорем 1.8 -г ашиглаж инволюцэн радикалын тухай дараах чухал теорем батлагдана.

Теорем 1.7. $\gamma$ нь уламюллагдах радикал байг. Тэгвэл $\gamma$ нь инволюиэн радикал радикал байх зайлшгүй бөгөөд хүрэлиээтэй нөхиөл бол $\gamma \cap \mathcal{A}=l_{\text {Ass }}(\gamma \cap \mathcal{A})=\gamma$ байх явдал юм.

Мөрдлөгөө 1.8. инволюцэн радикал оршин байна.

\section{2}

$\nu$-нь анхдагч цагирагуудаас тогтсон бөгөөд уламжлагдах, том өргөтгөлийн хувьд битүу бол тусгай анги гэнэ.

$U \nu$-радикалыг тусгай радикал гэдэг. Хэрэв тусгай анги $\nu$-нь дэд шулуун үл задрах цагирагуудаас тогтсон бол $U \nu$-г dual (давхар) тусгай радикал гэнэ.

Гомоморфизмын хувьд битүу цагиргуудын анги $M$-ийн хувьд харгалзан $\mathcal{L} M$ ба $\mathcal{L}_{s p} M$ ээр харгалзан $M$ ээр төрөгдсөн радикал болон тусгай радикалуудыг тэмдэглэе.

$\mathcal{P}$ ба $\mathcal{C}$ нь харгалзан бүх анхдагч цагираг ба бүх анхдагч энгийн цагирагуудын ангийг тэмдэглэе. [5] -д дараах үр дүнгүүд баталсан.

Өгүулбэр 2.1. $\rho=\mathcal{P} \cap S \mathcal{L}(\mathcal{C} \cup \beta)$ нь минималь идеал агуулаагүй бүх анхдагч цагирагуудыг тодорхойлно.

$(\eta, \xi)$ нь $\mathcal{C}$ ангийн хувааалт байг. Тэгвэл

$S(\xi)=\{A \in \mathcal{P} \mid A$ нь зүрхэвч $H(A) \in \xi$ байх дэд шулуун үл задрах цагираг $\}$

гэж тэмдэглэвэе.

Теорем $2.2([5]) \cdot \mathcal{L}_{s p} \eta=U \rho \varsubsetneqq U S(\xi)$

Мөн $\mathcal{A}_{S(\xi)}=\{A \in \mathcal{A} \mid A$ нь $S(\xi)$-д тэг биш гомоморф дүртэй $\}$ ба

$\mathcal{A}_{\xi}=\mathcal{A} \backslash \mathcal{A}_{S(\xi)}$ гэсэн тэмдэглэгээнүүдийг ашиглавал инволюцтэй цагирагуудтай холбогдсон теоремыг [5] -д баталсан харгалзах теоремтай төстэйгээр дараах чухал теорем батлагдана.

Теорем 2.3. $\mathcal{L}_{s p} \eta \subset \mathcal{L}_{s p} \mathcal{A}_{\xi} \subseteq U S(\xi)$ 
Хэдийгээр энэ теоремын баталгаа нь инволюцтэй байх албагүй тохиолдолд баталсан теоремын баталгаатай төсөөтэй боловч инволюцтэй цагираг инволюцтэй байх албагүй байх цагирагуудын чухал холбоог дараах мөрдлөгөөнүүд гаргаж байгаагаараа их онцлог юм.

Мөрдлөгөе 2.4. Хэрэв $\eta$-нъ инволюитэй бүх энгийн цагирагуудын анги бол $\mathcal{L}_{s p} \eta \subset \mathcal{L}_{s p} \mathcal{A} \subseteq U S(\xi)$.

Мөрдлөгөе 2.5. Хэрэв $\xi$-нь нэгжтэй ба инволючгүй бүх энгийн иагирагуудын анги бол $\mathcal{L}_{s p} \eta \subset \mathcal{L}_{s p} \mathcal{A} \subset U S(\xi)$.

$A$ цагирагийн төвийг $C(A)$ гэж тэмдэглэе.

$\mathcal{P}=\{A \mid A$ нь анхдагч цагираг ба дурын $0 \neq I \triangleleft A$ ийн хувьд $I \cap C(A) \neq 0\}$

[6], Пучиловский ба Смоктунович нар

$$
U \mathcal{P}=\{A \mid A[x] \in \mathcal{G}, \text { ҮҮнд } \mathcal{G} \text { нь Броун-Моккая радикал }\}
$$

болохыг харуулсан.

[7] -д Төмөрбат ба Вигандт нар $A \in U \mathcal{P}$ байх зайлшгүй бөгөөд хүрэлцээтэй нөхцөл бол дурын элемент $a \in A$ ийн хувьд $a_{1}, a_{2}, \ldots, a_{n}, b_{1}, b_{2}, \ldots, b_{m},(n, m \in Z)$ элементүүд олдоод $a^{m}+\sum_{i=1}^{n} a_{i}\left[a, b_{i}\right]=0$ адилтгал биелэхийг баталсан. Энд $\left[a, b_{i}\right]=$ $a b_{i}-b_{i} a$.

Дээрх чанаруудын $\mathcal{A}$-д проекцлон төстэйгээр батлахад дараах теорем гарна.

Теорем 2.6. $A \in U \mathcal{P} \cap \mathcal{A}$ байх зайлшгүй бөгөөд хүрэлиээтэй нөхиөл нъ $A$ ийн дурын боломжит дэд цагираг нъ $*$-дэд цагираг бөгөөд дурын $a \in A$ элементийн хувъд $a_{1}, a_{2}, \ldots, a_{n}, b_{1}, b_{2}, \ldots, b_{m},(n, m \in Z)$ элементүүд олдоод

$$
a^{*^{m}}+\sum_{i=1}^{n}\left[a^{*}, b_{i}^{*}\right] a_{i}^{*}=0
$$

адилтгал биелнэ.

\section{Ашигласан ном}

[1] Divinsky.N, Rings and radicals, Allen and Unwin, 1965.

[2] Szász.F.A, Radicals of rings, Journal Budapest, Akadémiai Kiadó, 1981.

[3] Gardner.B and Wiegandt.R, Radical Theory of rings, Monograph Textbooks, Pure Appl. Math. 261. Marcel Dekker, 2004.

[4] Gardner.B and Wiegandt.R, Characterizing and constructing special radicals, Acta Math. Acad. Sci. Hungar. 40 (1982), 73-83. 
[5] Tumurbat.S and Wiegandt.R, A note on special radicals and partitions of simple rings, Comm. in Algebra, 30 (4), (2002), 1769-1777.

[6] Puczylowski.E.R and Smoktunowicz.A, On maximal ideals and the Brown-McCoy radical of polynomial rings, Comm. in Algebra, 26, (1988), 2473-2482.

[7] Tumurbat.S and Wiegandt.R, On polynomial and multiplicative radicals, Quaest. Math. 26 (2003), No. 4, 453-469.

[8] Tumurbat.S and Zand.H, On small and large radicals, Quaest. Math. 22 (1999), 195-202. 


\title{
ON RADICALS OF RINGS AND RADICALS OF RINGS WITH INVOLUTION
}

\author{
S.Tumurbat ${ }^{1}$, Sh.Batkhishig ${ }^{2}$ \\ ${ }^{1}$ Department of Mathematics, National university of Mongolia, Mongolia \\ ${ }^{2}$ Department of Mathematics, Mongolian university of Education, Mongolia \\ e-mail:stumurbat@hotmail.com,batkhishig@msue.edu.mn
}

\begin{abstract}
We define the concept of involution radical and prove some properties of hereditary involution radicals. In addition, we consider partition of simple rings and prove a stronger version of a known result.
\end{abstract}

